\title{
Aerosol Best Estimate (AEROSOLBE) Value-Added Product
}

\author{
C Flynn \\ D Turner \\ A Koontz \\ D Chand \\ C Sivaraman
}

July 2012 


\section{DISCLAIMER}

This report was prepared as an account of work sponsored by the U.S. Government. Neither the United States nor any agency thereof, nor any of their employees, makes any warranty, express or implied, or assumes any legal liability or responsibility for the accuracy, completeness, or usefulness of any information, apparatus, product, or process disclosed, or represents that its use would not infringe privately owned rights. Reference herein to any specific commercial product, process, or service by trade name, trademark, manufacturer, or otherwise, does not necessarily constitute or imply its endorsement, recommendation, or favoring by the U.S. Government or any agency thereof. The views and opinions of authors expressed herein do not necessarily state or reflect those of the U.S. Government or any agency thereof. 


\title{
Aerosol Best Estimate (AEROSOLBE) Value-Added Product (VAP)
}

\author{
C Flynn \\ D Turner \\ A Koontz \\ D Chand \\ C Sivaraman
}

July 2012

Work supported by the U.S. Department of Energy,

Office of Science, Office of Biological and Environmental Research 


\section{Acronyms and Abbreviations}

$\begin{array}{ll}\text { AEROSOLBE } & \text { Aerosol Best Estimate (value-added product) } \\ \text { AIP } & \text { Aerosol Intensive Properties (value-added product) } \\ \text { AOD } & \text { aerosol optical depth } \\ \text { AOS } & \text { aerosol observing system } \\ \text { ARM } & \text { Atmospheric Radiation Measurement (Climate Research Facility) } \\ \text { BBHRP } & \text { Broadband Heating Rate Profile (value-added product) } \\ \text { bsf } & \text { backscatter fraction } \\ \text { g } & \text { asymmetry parameter } \\ \text { MERGESONDE } & \text { Merged Sounding (value-added product) } \\ \text { MET } & \text { meteorological instrumentation } \\ \text { MFRSR } & \text { multifilter rotating shadowband radiometer } \\ \text { NIMFR } & \text { normal incidence multifilter radiometer } \\ \text { PSAP } & \text { particle soot absorption photometer } \\ \text { RH } & \text { relative humidity } \\ \text { RL } & \text { Raman lidar } \\ \text { SGP } & \text { Southern Great Plains } \\ \text { SSA } & \text { single-scattering albedo } \\ \text { VAP } & \text { value-added product }\end{array}$




\section{Contents}

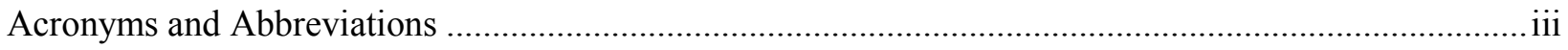

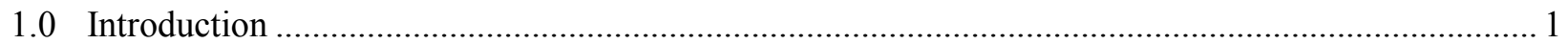

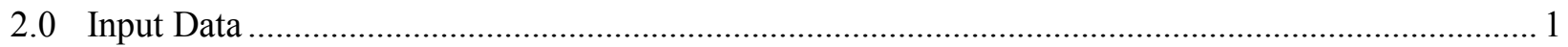

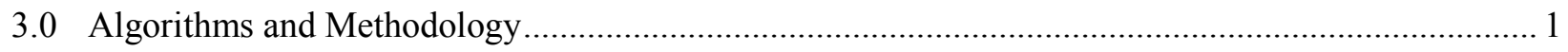

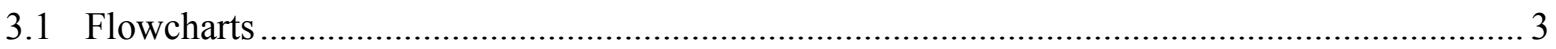

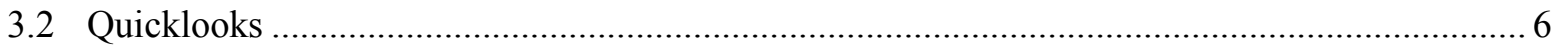

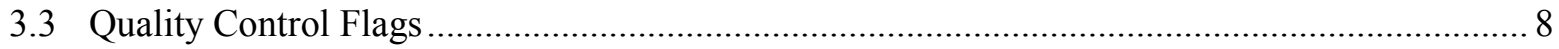

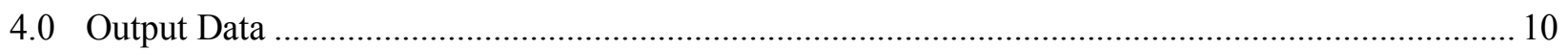

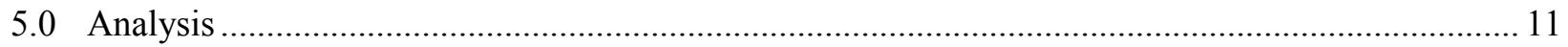

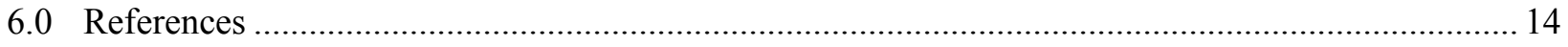

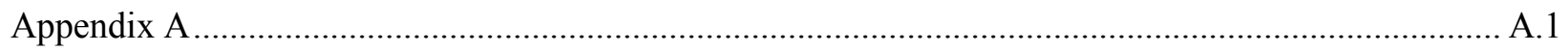

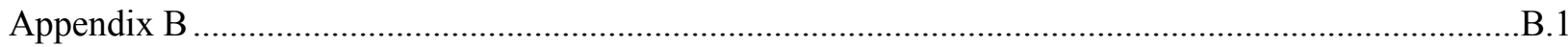

\section{Figures}

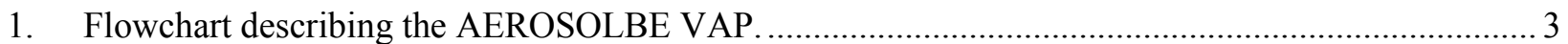

2. Flowchart describing the process of calculating the best-estimate aerosol optical depth at $355 \mathrm{~nm} \ldots . .4$

3. Flowchart describing the process of calculating best-estimate aerosol optical depth at $500 \mathrm{~nm}$.........5

4. Flowchart describing the process of calculating the best estimate Angström exponent...................... 6

5. Example quicklook plots of monthly time series for aerosol extinction and aerosol optical depth.... 7

6. Example quicklook plots of monthly time series for RH profile, SSA, and asymmetry parameter..... 8

7. Time-height cross section of the aerosol extinction, together with the AOD, for March 2000 derived

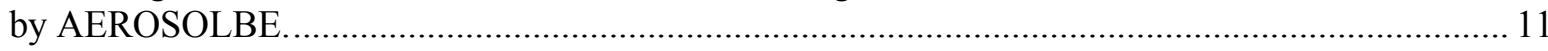

8. Mean aerosol extinction profiles as a function of season and AOD as observed by the RL in 19992000 (Turner et al. 2001)

9. $\mathrm{f}(\mathrm{RH})$ corrections for the red, green, and blue total scattering (top) and backscattering (bottom) coefficients from the AOS, using the median parameters from February 2000-February 2001 in the

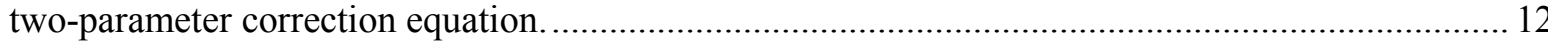

10. An example of the vertical profiles of $\mathrm{RH}, \omega_{0}$, and $\mathrm{g}$ for the month of March 2000 derived by AEROSOLBE.

11. Monthly distributions of observed minus predicted AOD as observed by the v1.0 effective height and v1.1 regression fit for 2000 .

\section{Tables}

1. The wavelengths and the associated parameters.

2. Gap within which data are interpolated if values are missing. ........................................................ 10

3. Quarterly Boundary layer height threshold based on Figure 11..................................................... 13

4. Input Platform and the associated fields. ........................................................................................... A.1

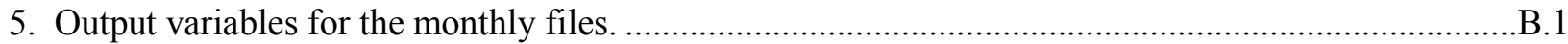




\subsection{Introduction}

The objective of the Aerosol Best Estimate (AEROSOLBE) value-added product (VAP) is to provide vertical profiles of aerosol extinction, single scatter albedo, asymmetry parameter, and Angström exponents for the atmospheric column above the Central Facility at the ARM Southern Great Plains (SGP) site. We expect that AEROSOLBE will provide nearly continuous estimates of aerosol optical properties under a range of conditions (clear, broken clouds, overcast clouds, etc.). The primary requirement of this VAP was to provide an aerosol data set as continuous as possible in both time and height for the Broadband Heating Rate Profile (BBHRP) VAP in order to provide a structure for the comprehensive assessment of our ability to model atmospheric radiative transfer for all conditions. Even though BBHRP has been completed, AEROSOLBE results are very valuable for environmental, atmospheric, and climate research.

After screening available aerosol optical depth (AOD) measurements for clouds and performing data quality checks, the VAP provides a nearly continuous time-series of aerosol optical depth at $500 \mathrm{~nm}$ and aerosol Angström exponent through a combination of simple interpolation and a predictive multivariate regression. The associated extinction profile is selected from the Raman lidar (RL) seasonal climatology of aerosol extinction profiles as a function of aerosol optical depth published in Turner et al. (2001). Single scatter albedo $\left(\omega_{0}\right)$ and asymmetry parameter $(\mathrm{g})$ profiles are derived by assuming that the dry aerosol scattering properties measured by the aerosol observing system (AOS) at the surface are wellmixed with height. The aerosol absorption is assumed to have no humidity dependence. The aerosol optical properties are then modulated according to the vertical relative humidity $(\mathrm{RH})$ profile using the surface measured $\mathrm{f}(\mathrm{RH})$ relationship as derived from aipfitrhlogren data.

This application is currently implemented for the Southern Great Plains only.

\subsection{Input Data}

The algorithm currently utilizes measurements from these datastreams:

1. Normal incidence multifilter radiometer (NIMFR), using the nimfraod1mich datastream

2. Multifilter rotating shadowband radiometer (MFRSR), using the mfrsraod1 mich datastream

3. Surface aerosol properties from the aerosol observing system (AOS), using the aip1 ogren and aipfitrhlogren datastreams

4. Relative humidity from radiosonde (mergesonde1mace datastream)

5. Surface humidity from surface meteorological instrumentation (MET) data (met datastream).

The input variables are given in Appendix A.

\subsection{Algorithms and Methodology}

The most important optical property of aerosols for radiative transfer applications is the AOD. Therefore, significant effort is made in AEROSOLBE to obtain good estimates of AOD. The AEROSOLBE time resolution is set to 10 minutes, so data from each input source are averaged to achieve this temporal 
resolution. The AEROSOLBE algorithm currently incorporates two direct measurements of AOD: the nimfraod1mich datastream from the NIMFR and the mfrsraod1mich datastream from the MFRSR, with the NIMFR taken in preference over the MFRSR due to lack of necessary cosine correction for the NIMFR (Harrison and Michalsky 1994). If the above two sources are unavailable for a given sample, then the data are interpolated over short gaps. For longer gaps the AOD is predicted using a multivariate regression that includes the surface $\mathrm{RH}$, surface total scattering, and the average $\mathrm{RH}$ in the boundary layer. The coefficients of the regression are optimized over a monthly data set to minimize residuals when direct measurements are available.

AEROSOLBE reports time/height profiles of aerosol extinction at $500 \mathrm{~nm}$ estimated via a seasonal climatology of RL extinction profiles as a function of column optical depth. AEROSOLBE provides bestestimate time/height profiles of intensive properties of single-scattering albedo (SSA), backscatter fraction (bsf), and asymmetry parameter ( $\mathrm{g}$ ) for the red, green, and blue wavelengths estimated from surface measurements (from the Aerosol Intensive Properties [AIP] VAP) and the vertical profile of relative humidity (from the Merged Sounding [MERGESONDE] VAP), along with the assumption that the dry aerosol properties are vertically well-mixed. The well-mixed assumption allows the humidity dependence measured at the surface to be applied to the vertical column, yielding estimates for the ambient aerosol scattering that reflect the vertical structure in the humidity field, while the ratios involved in computing the intensive properties (SSA, bsf, g) mitigate scale-height effects on the extensive aerosol profiles.

After the best-estimate of the AOD at $500 \mathrm{~nm}$ is determined, a lookup table is used to determine the aerosol extinction profile based upon the climatology developed from two years of RL observations (Turner et al. 2001). This lookup table is organized as a function of season and AOD.

AEROSOLBE also provides estimates of the single scatter albedo $\left(\omega_{0}\right)$ and asymmetry parameter $(\mathrm{g})$ as a function of height. These values are derived from the surface-based in situ measurements made by the AOS as follows. First, the boundary layer is assumed to be well-mixed such that the dry aerosol optical properties are constant with altitude (or at least constant in relative proportion). Next, relative humidity profiles are drawn from the MERGESONDE VAP, which provides estimates of the relative humidity for all times and heights above the SGP Central Facility. The surface level relative humidity from MERGESONDE is replaced with the surface RH obtained from MET data. Next, the aerosol optical properties of total scattering and hemispheric backscattering are computed for the vertical column by adjusting the dry properties according to the vertical profile of relative humidity. The two-parameter fit provided as part of the AOS (aosfrh) data stream $f(R H)=a(1-u)^{-b}$, where $u$ is the relative humidity interpolated from the radiosonde observation as a fraction, is used to rehumidify the dry aerosol scattering properties. Note that no humidity correction is applied to the aerosol absorption coefficient observed by the AOS. The aerosol optical properties of scattering and absorption as well as the related intensive properties of single-scattering albedo and asymmetry parameter are each reported at the wavelengths adopted in the AIP VAP. Specifically, the nominal red, green, and blue measurements from the nephelometer and the 3-wavelength particle soot absorption photometer (PSAP), initially taken at different wavelengths, are adjusted via Angström exponent relationships to common wavelengths of $660 \mathrm{~nm}, 550 \mathrm{~nm}$, and $467 \mathrm{~nm}$. 


\subsection{Flowcharts}

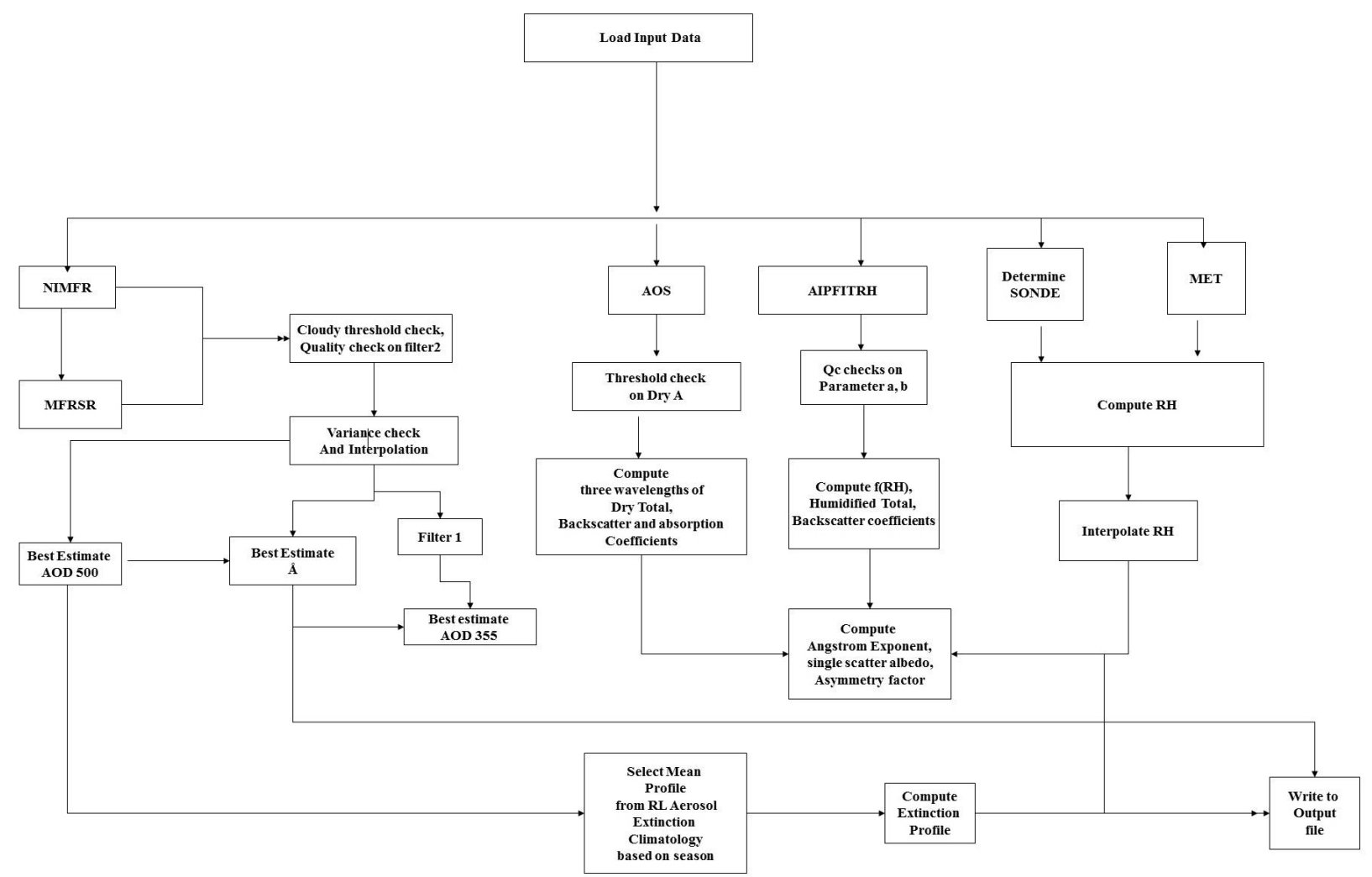

Figure 1. Flowchart describing the AEROSOLBE VAP. 


\section{Best Estimate AOD 355}

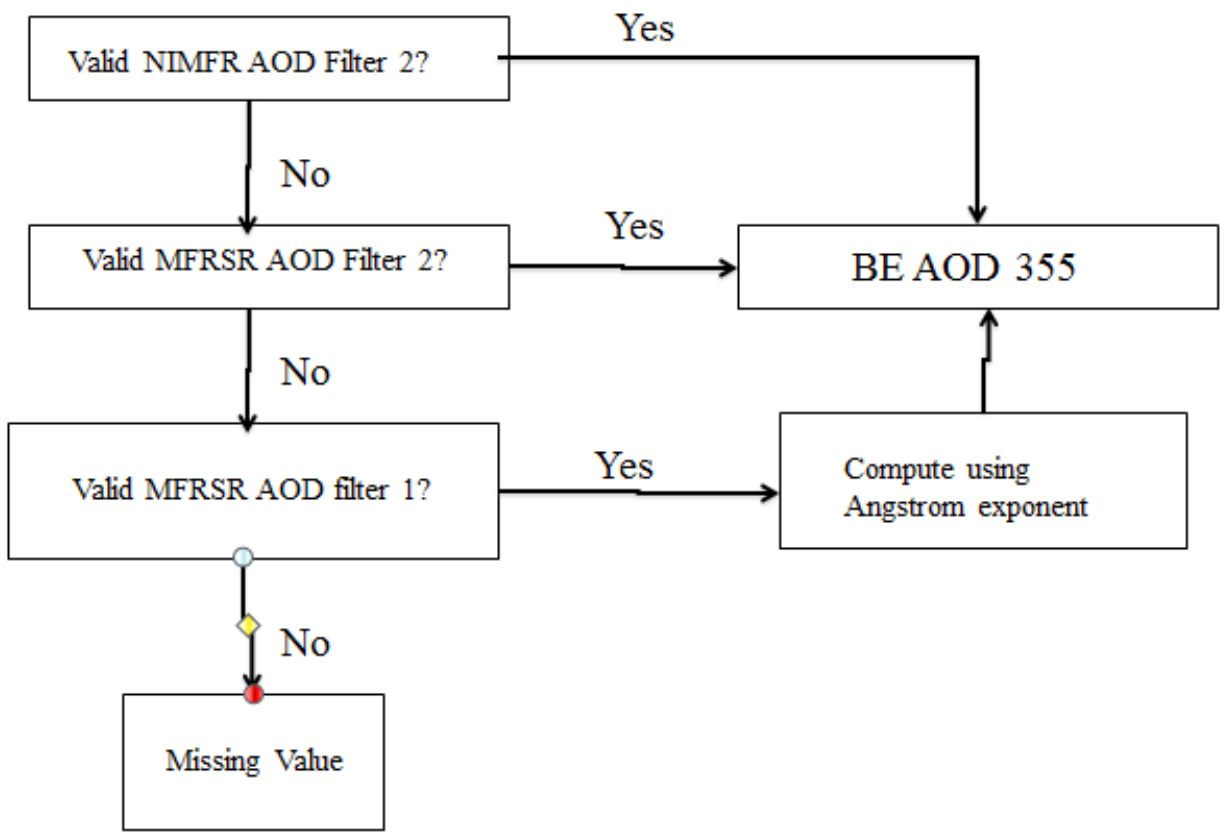

Figure 2. Flowchart describing the process of calculating the best-estimate aerosol optical depth at $355 \mathrm{~nm}$. 


\section{Best Estimate AOD 500}

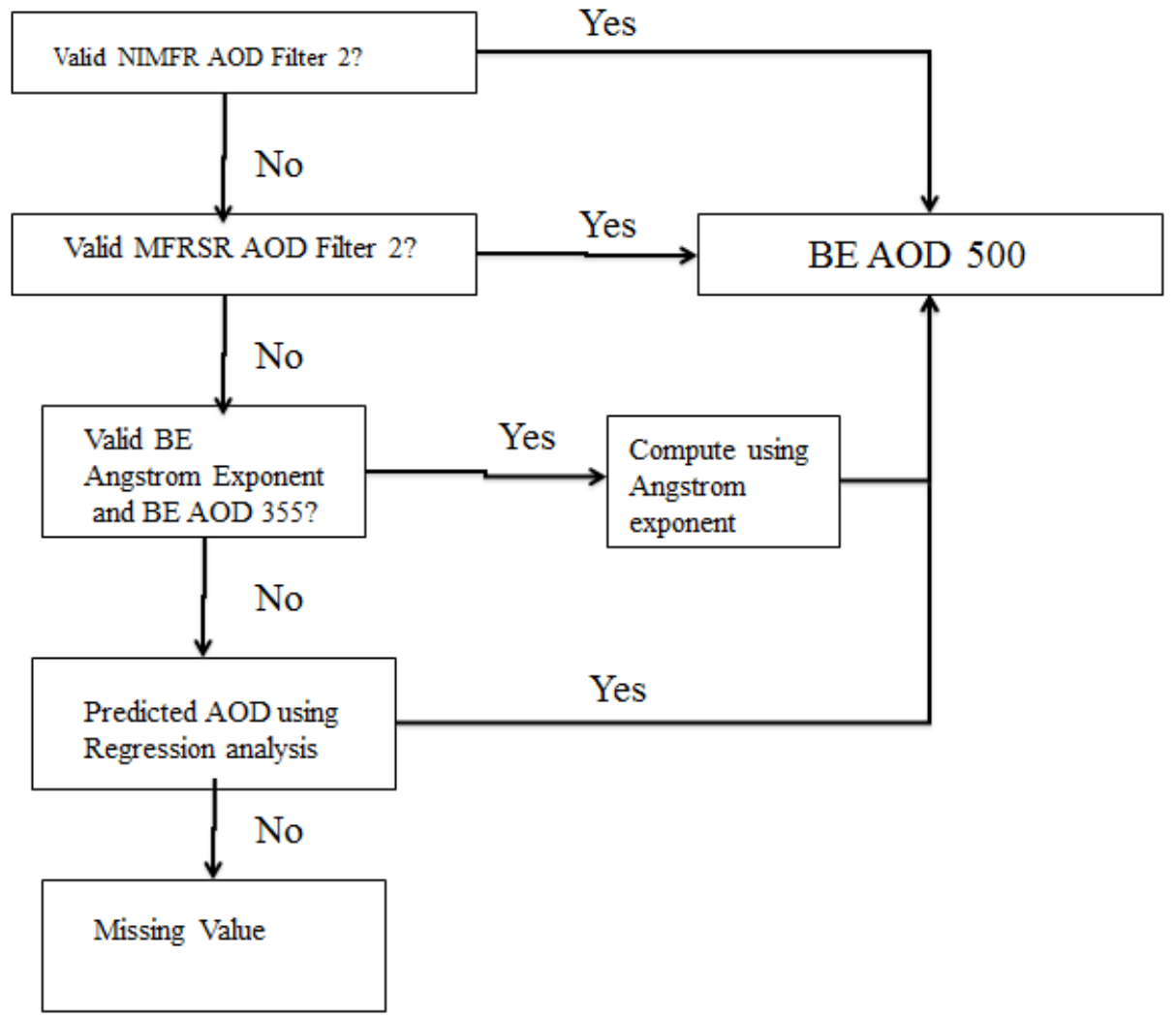

Figure 3. Flowchart describing the process of calculating best-estimate aerosol optical depth at $500 \mathrm{~nm}$. 


\section{Best-Estimate Angstrom Exponent}

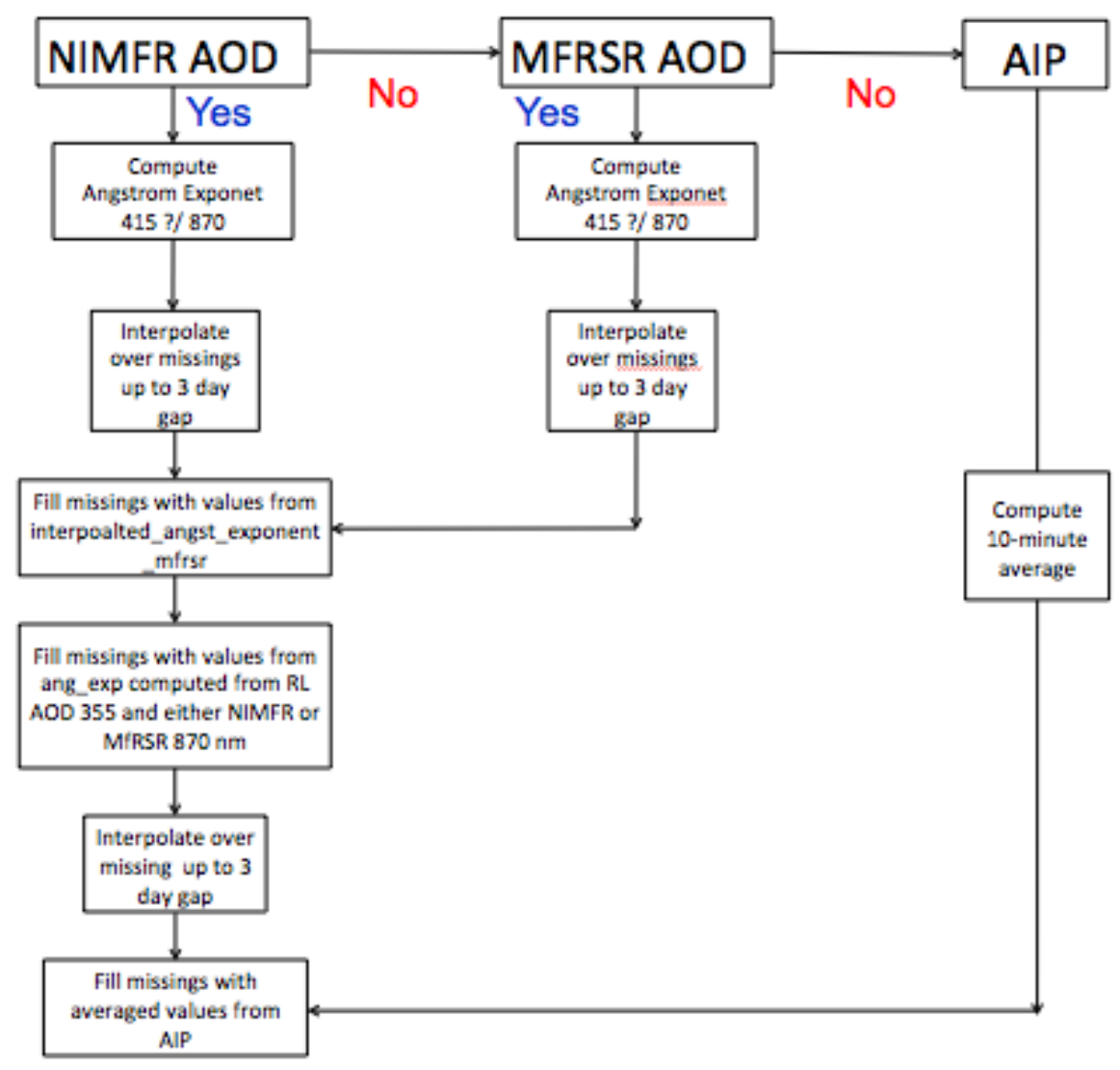

Figure 4. Flowchart describing the process of calculating the best estimate Angström exponent.

\subsection{Quicklooks}

Quicklook plots of monthly time series are generated for column AOD, vertical profiles up to $4 \mathrm{~km}$ of aerosol extinction, SSA, and g, and for the corresponding RH profile. The optical properties are shown for the nominal green wavelength of $500 \mathrm{~nm}$. 
C Flynn, D Turner, A Koontz, D Chand, and C Sivaraman, July 2012, DOE/SC-ARM/TR-115
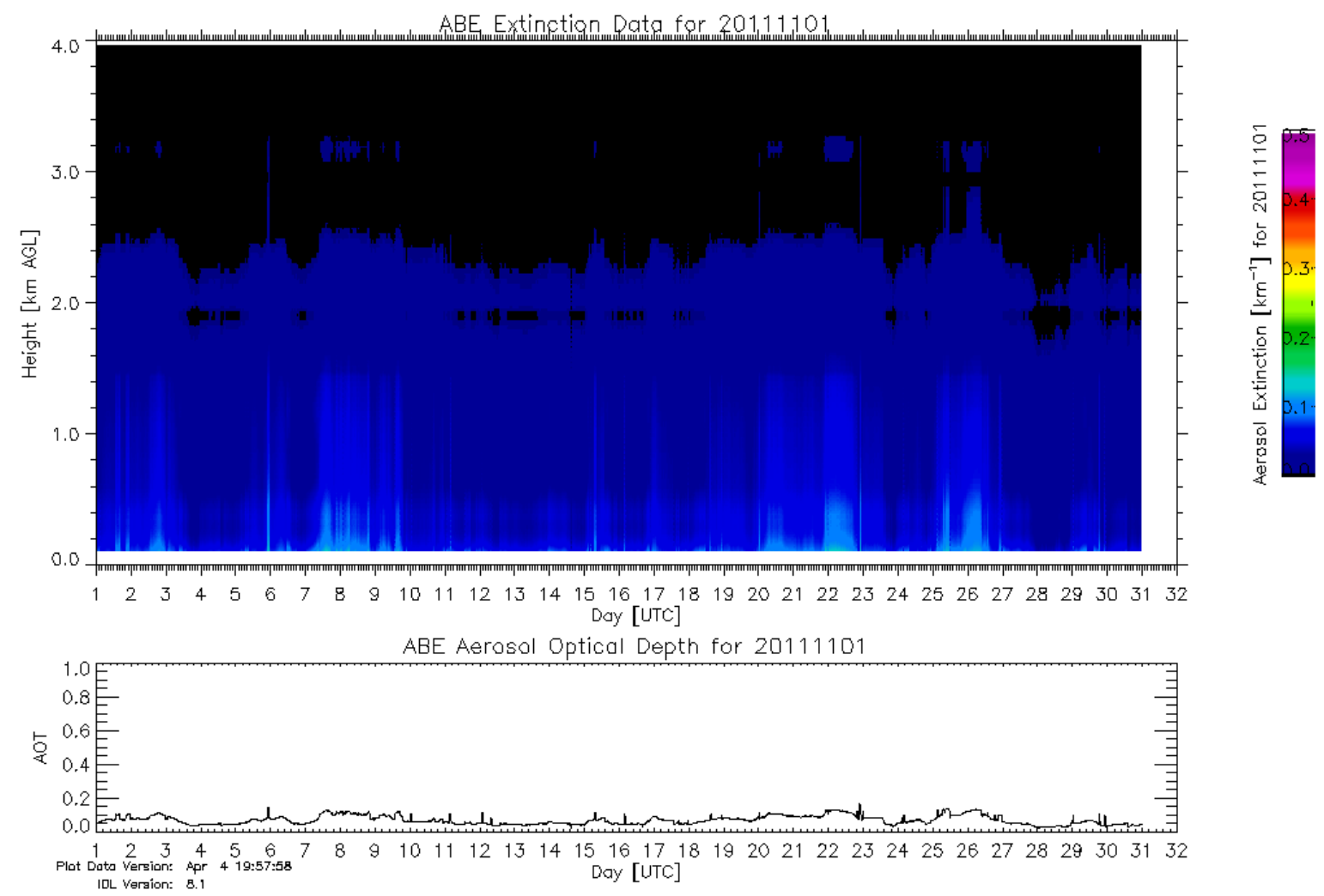

Figure 5. Example quicklook plots of monthly time series for aerosol extinction and aerosol optical depth. 


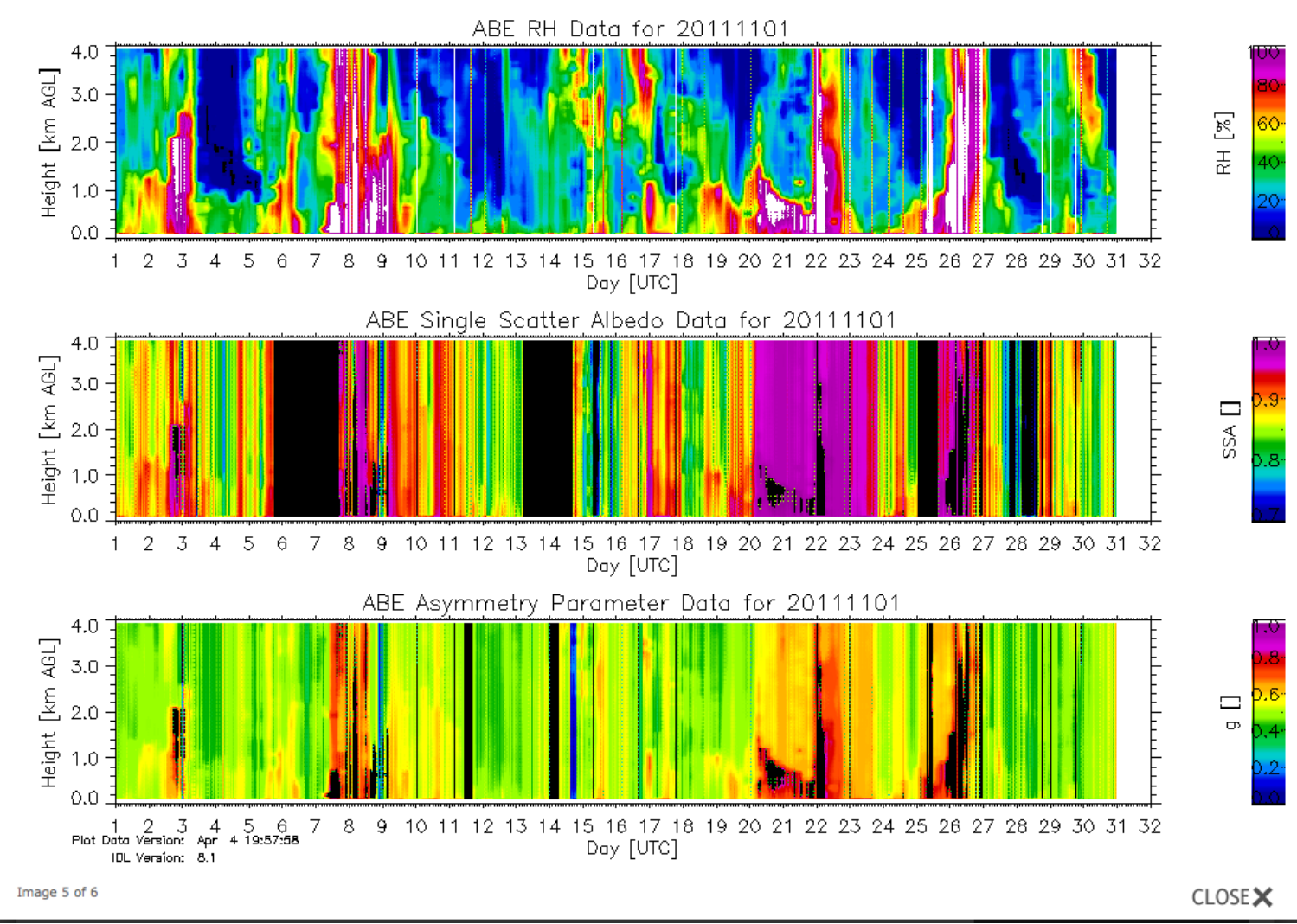

Figure 6. Example quicklook plots of monthly time series for RH profile, SSA, and asymmetry parameter.

\subsection{Quality Control Flags}

Each datastream goes through a series of quality checks. The quality checks performed for the input datastream are explained below:

1. The nimfraod 1 mich and mfrsraod 1 mich datastreams are checked for anomalies by performing the following tolerance test, which establishes a rolling window of 90 samples before and after the sample of interest is established.

a. Calculate the mean and standard deviation of the samples in the window.

i. If the standard deviation of the window is greater than .05 and the difference between the absolute value of the sample of interest and the mean value of the window is greater than .05 , then the sample of interest is flagged as bad data and replaced with missing value of -9999.0. But after running through a series of data and analyzing the data on October 2004, the test was changed to the following:

ii. If the standard deviation of the window is greater than .05 , the sample of interest is flagged as bad data and replaced with missing value of -9999.0 .

b. The rolling window is then moved up by one sample.

2. Once the data have passed the tolerance test, the nimfraod 1 imch or mfrsraod1mich data stream is screened for clouds. If the Angström exponent is less than the cloudy threshold of 0.5 or greater than 4.0, then the aerosol optical depths for all the filters are replaced with missing values of -9999.0. 
3. The dry Angström exponent from the aiplogren is screened for bad data as well. If the dry Angström exponent for total scattering, back scattering, and absorption coefficients is not within a range of 0 and 3, then these values are replaced with missing values of -9999.0 .

4. The mergesonde1mace profile is discarded if it does not reach a minimum height of $7 \mathrm{~km}$. The relative humidity from SONDE data is set to a minimum value of $50 \%$ if the humidity is less than zero.

5. The relative humidity from MET data is set to $99 \%$ if the humidity value is above 99.0 .

6. The two-parameter fit provided in the aipfitrhlogren data stream is used to compute $f(R H)$ and thus "rehumidify" the scattering coefficients to ambient conditions. This function has the form $f(R H)=$ $a(1-R H)^{-b}$, where RH is given as a fraction between 0 and 1 and $a$ and $b$ are in the netCDF file as parameters 1 and 2 respectively. The fields for red, blue, and green total and back scatter coefficients from the aipfrh datastream (i.e., parameters 1 and 2) are also checked for quality. The maximum RH range for red, blue, and green is checked to make sure that it is greater than $70 \%$, and the minimum $\mathrm{RH}$ range for red, blue, and green is checked to make sure that it is less than $50 \%$. Then, the red, blue, and green total scattering parameters $a$ and $b$ are checked to make sure that they fall within the range of 0.2 and 1.4, respectively. If the parameters are out of range, they are set to -9999 . Finally, the fit parameters are checked to ensure that they are within certain limits, and if not, they are set to prescribed values. See Table 1 below.

Table 1. The wavelengths and the associated parameters.

\begin{tabular}{|l|l|l|}
\hline Wavelength & Parameter 1 (a) & Parameter 2 (b) \\
\hline Green & 0.8043 & 0.4436 \\
\hline Blue & 0.8345 & 0.3920 \\
\hline Red & 0.7619 & 0.4878 \\
\hline
\end{tabular}




\section{Interpolation}

This VAP uses linear regression to interpolate data when data are missing for a certain period of time. The period of time for which the data are interpolated varies by data quantity. The table below gives the gap within which data are interpolated if the values are missing. If any gap is greater than the interval shown, then the values are not interpolated.

Table 2. Gap within which data are interpolated if values are missing.

\begin{tabular}{|l|l|}
\hline Field & Interval \\
\hline Best estimate Angström exponent & 3 days \\
\hline Best estimate aerosol optical depth at 355nm & 3 hours \\
\hline $\begin{array}{l}\text { Best estimate aerosol optical depth at } 500 \mathrm{~nm} \\
\text { before using regression analysis }\end{array}$ & 3 hours \\
\hline $\begin{array}{l}\text { Best estimate aerosol optical depth at } 500 \mathrm{~nm} \\
\text { after using regression analysis }\end{array}$ & 8 hours \\
\hline All dry coefficients from aip1ogren & 3 hours \\
\hline $\begin{array}{l}\text { f(RH) correction coefficients } \\
\text { All humidified total scattering and back scatter } \\
\text { coefficients across time and height }\end{array}$ & 3 hours \\
\hline $\begin{array}{l}\text { Angström exponent using humidified Red and } \\
\text { Blue total scattering coefficient }\end{array}$ & 3 days \\
\hline $\begin{array}{l}\text { Single scatter albedo } \\
\text { Asymmetry factor }\end{array}$ & 3 hours \\
\hline
\end{tabular}

\subsection{Output Data}

sgpaerosolbe1turnFF.c1.YYYYMMDD.hhmmss where:

- aerosolbe $=$ VAP class

- 1 turn = identifies that this is Turner's version 1 of aerosol best estimate

- $\mathrm{FF}=$ facility (e.g., C1)

- YYYYMMDD = year, month, and day

- hhmmss = hour, minute, second

Currently, AEROSOLBE is executed only for the SGP Central Facility. 


\subsection{Analysis}

Data from 2000 were processed with AEROSOLBE as part of the ongoing BBHRP effort (Mlawer et al. 2004). A time-height cross section of aerosol extinction for March 2000 is provided in Figure 7. Figure 8 is a plot of the mean extinction profiles as drawn from the RL climatology as a function of season and AOD. The extinction profile for this VAP is picked from the climatology based on the AOD, bin, and season. Figure 9 shows the hygroscopic growth function $\mathrm{f}(\mathrm{RH})$ for the red, green, and blue total scattering (top) and backscattering (bottom) coefficients from the AOS, using the median parameters from Feb 2000-Feb 2001 in the two-parameter correction equation. An example of the vertical profiles of $\mathrm{RH}, \omega_{0}$, and $\mathrm{g}$ for the month of August 2000 derived by AEROSOLBE is shown in Figure 10. The monthly distributions of observed minus predicted AOD as observed by the v1.0 effective height and v1.1 regression fit for 2000 are illustrated in Figure 11.
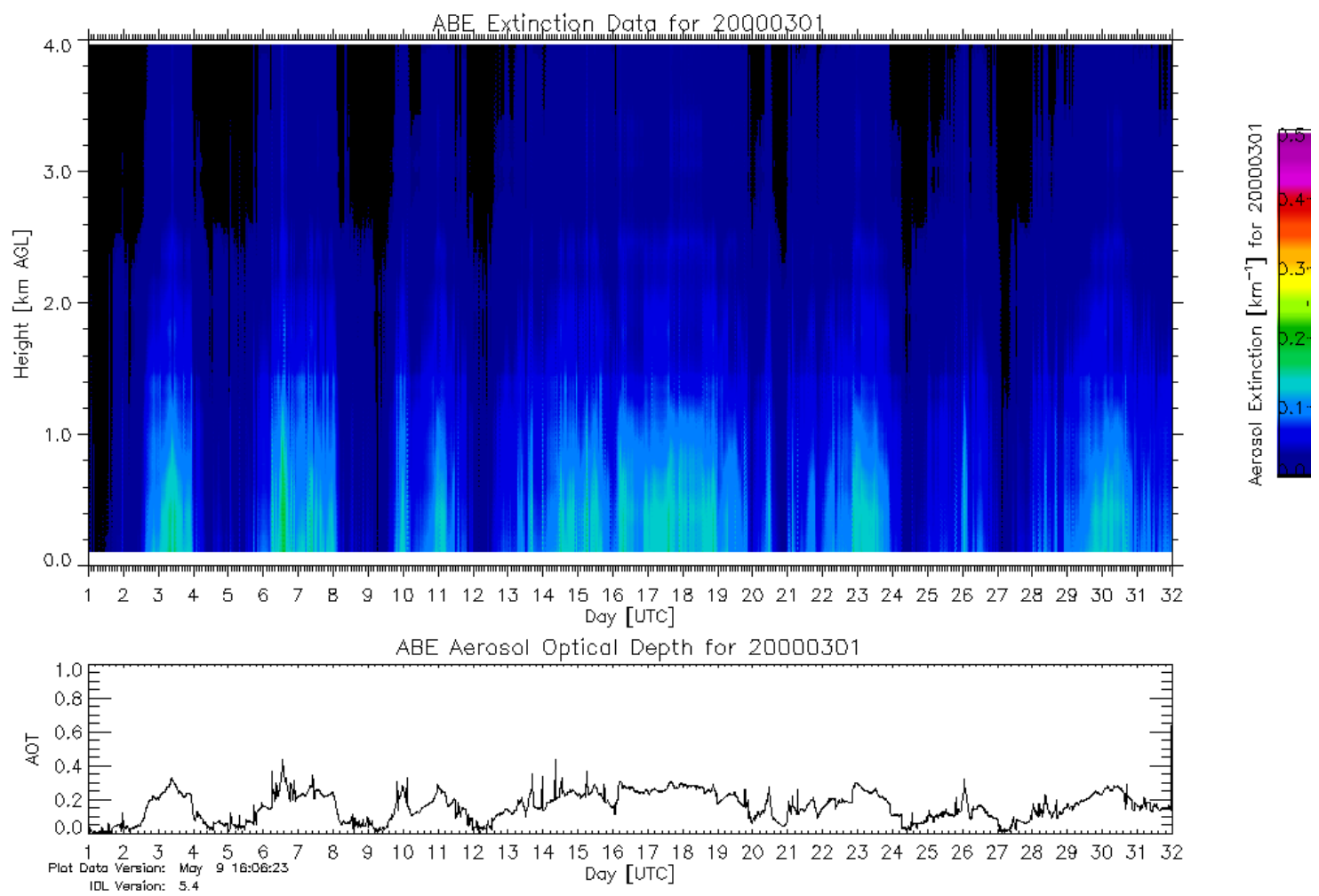

Figure 7. Time-height cross section of the aerosol extinction, together with the AOD, for March 2000 derived by AEROSOLBE. 


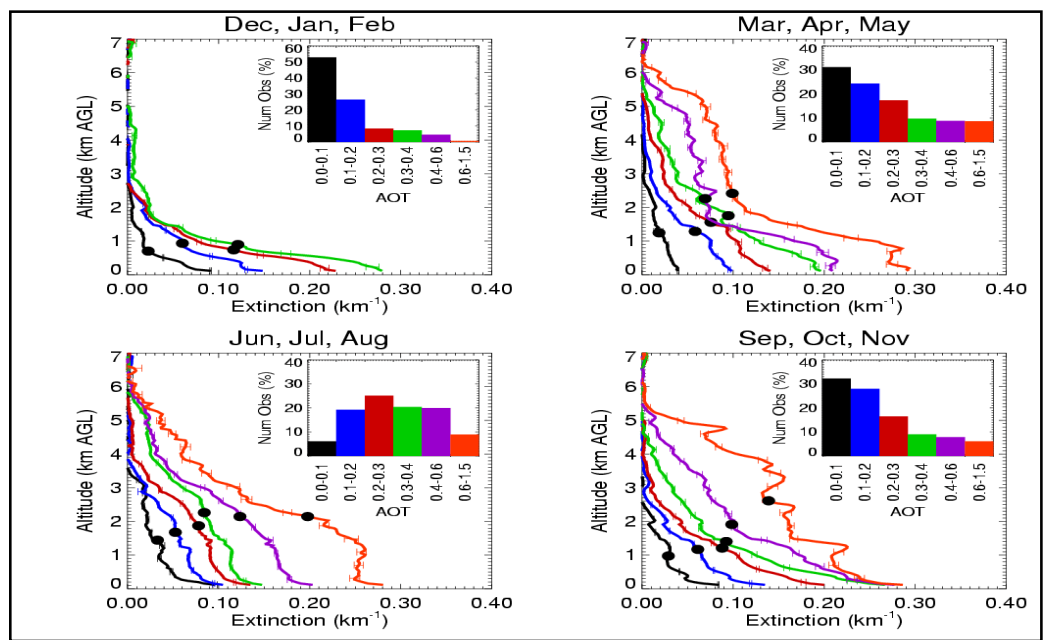

Figure 8. Mean aerosol extinction profiles as a function of season and AOD as observed by the RL in 1999-2000 (Turner et al. 2001).

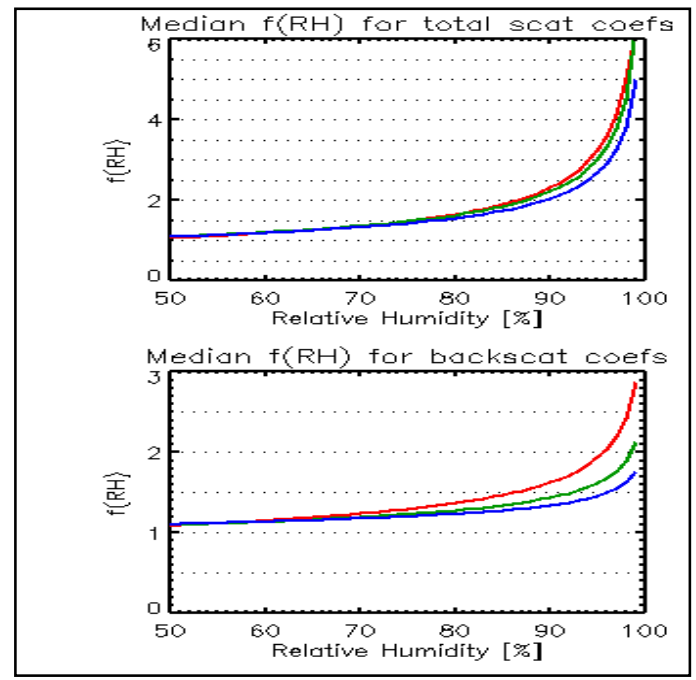

Figure 9. $\quad \mathrm{f}(\mathrm{RH})$ corrections for the red, green, and blue total scattering (top) and backscattering (bottom) coefficients from the AOS, using the median parameters from February 2000 to February 2001 in the two-parameter correction equation. 


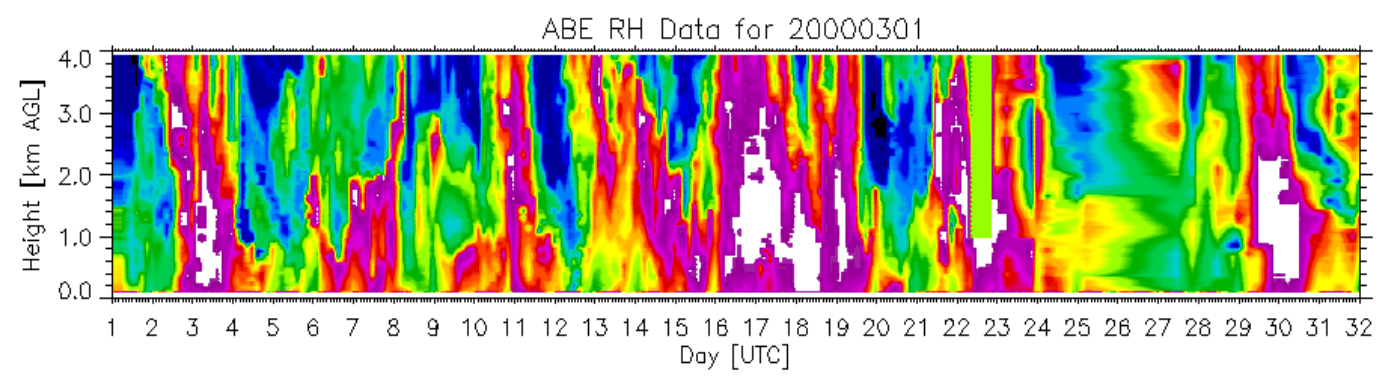

ABE Single Scatter Albedo Dato for 20000301
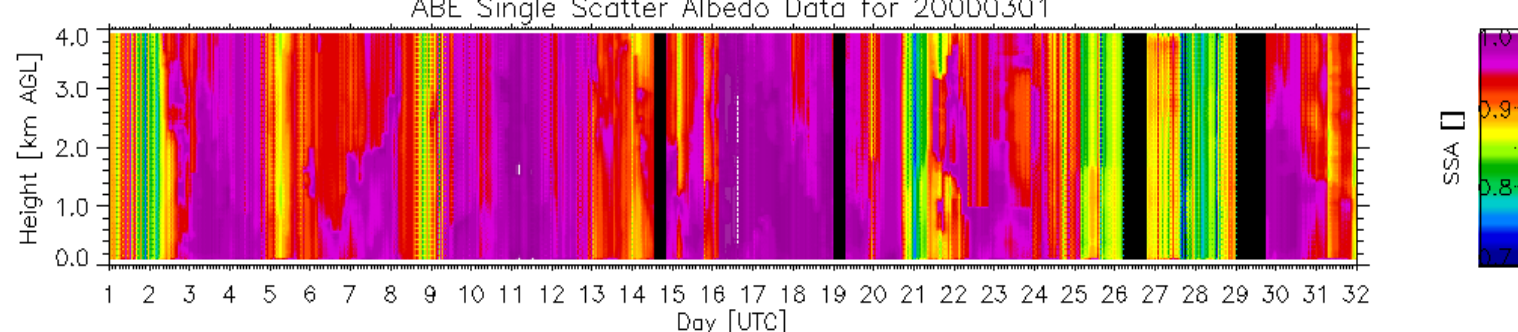

ABE Asymmetry Parameter Data for 20000301
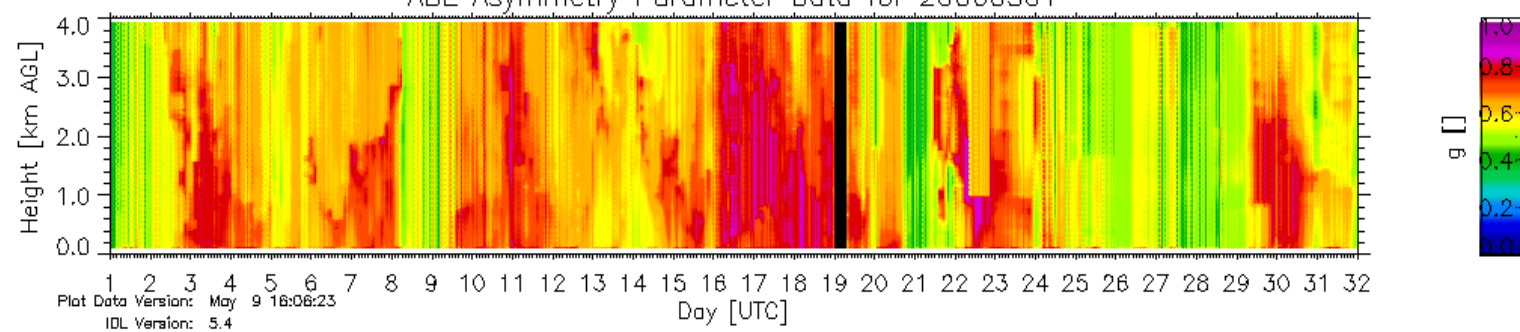

Figure 10. An example of the vertical profiles of $\mathrm{RH}, \omega_{0}$, and $\mathrm{g}$ for the month of March 2000 derived by AEROSOLBE.

Table 3. Quarterly Boundary layer height threshold based on Figure 11.

\begin{tabular}{|c|c|}
\hline Month & Boundary-layer height \\
\hline December/January/February & 1.0 \\
\hline March/April/May & 1.7 \\
\hline June/July/August & 2.0 \\
\hline September/October/November & 1.5 \\
\hline
\end{tabular}




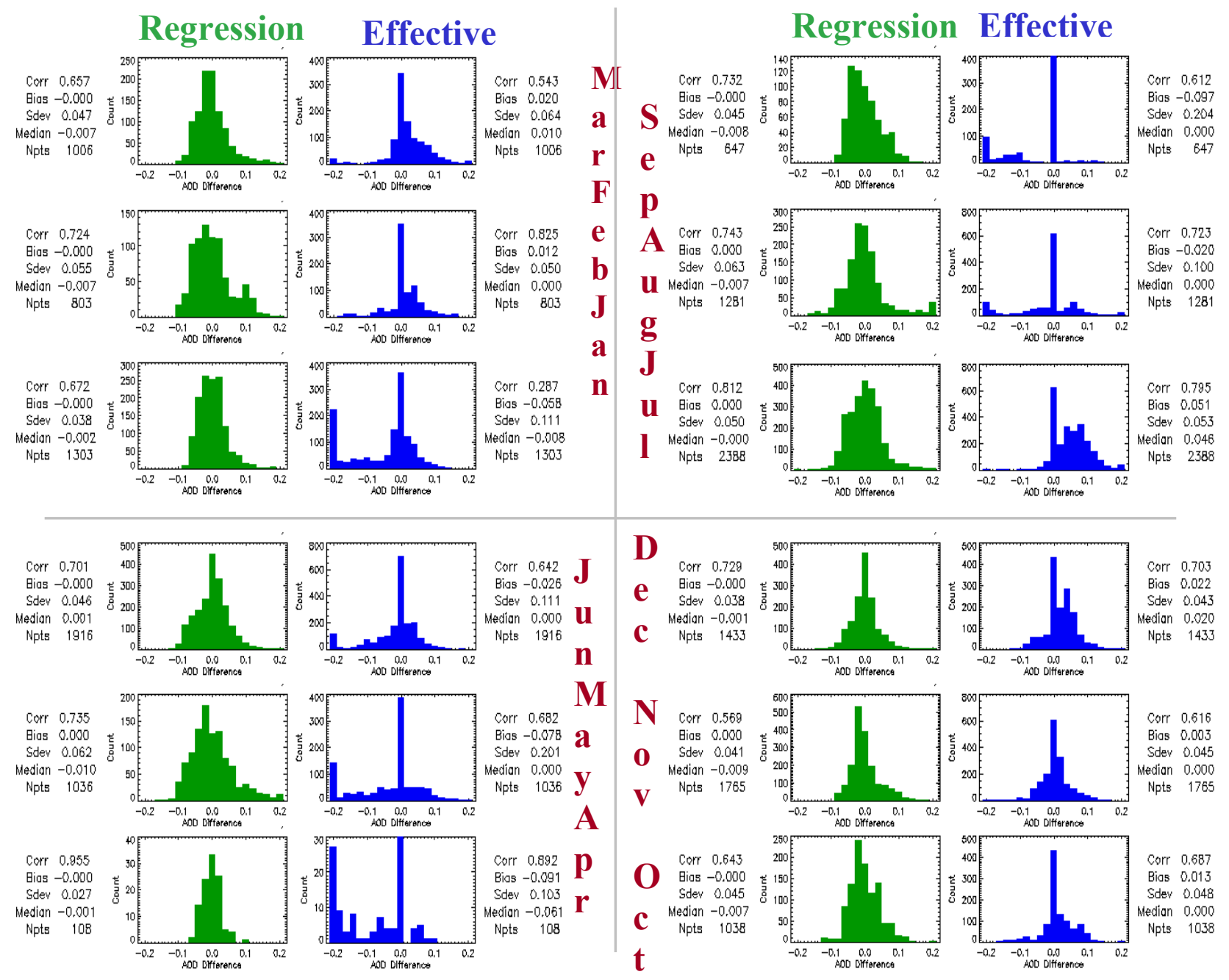

Figure 11. Monthly distributions of observed minus predicted AOD as observed by the v1.0 effective height and v1.1 regression fit for 2000.

\subsection{References}

Andrews, E, et al. 2006. "Comparison of methods for deriving aerosol asymmetry parameter." Journal of Geophysical Research 111: D05S04. DOI:10.1029/2004JD005734.

Andrews, E, PJ Sheridan, JA Ogren, and R Ferrare. 2004. "In situ aerosol profiles over the Southern Great Plains CART site, Part I: Aerosol optical properties." Journal of Geophysical Research 109: D06208. DOI:10.1029/2003JD004025.

Daniel, JS, et al. 2002. "Cloud liquid water and ice measurements from spectrally resolved near-infrared observations: A new technique.” Journal of Geophysical Research 107: 4599.

DOI:10.1029/2001JD000688. 
Ferrare, RA, et al. 2004. "Raman lidar measurements of aerosols and water vapor over the Southern Great Plains." Proceedings of the 22nd International Laser Radar Conference (ILRC), Matera, Italy.

Flynn, CJ, A Mendoza, and J Christy. 2004. "ARM Micropulse lidar: Configuration upgrades and new data products." Proceedings of the 14th ARM Science Team Meeting, Albuquerque, New Mexico.

Goldsmith, JEM, FH Blair, SE Bisson, and DD Turner. 1998. "Turn-key Raman lidar for profiling atmospheric water vapor, clouds, and aerosols." Applied Optics 37: 4979-4990.

Harrison, LC, and JJ Michalsky. 1994. "Objective algorithms for the retrieval of optical depths from ground-based measurements." Applied Optics 33: 5126.

Koontz, AS, CJ Flynn, JA Ogren, E Andrews, and PJ Sheridan. 2003. "ARM AOS processing status and aerosol intensive properties VAP." Proceedings of the 13th ARM Science Team Meeting, Broomfield, Colorado.

Mlawer, EJ, et al. 2002. "The broadband heating rate profile (BBHRP) VAP." Proceedings of the 12th ARM Science Team Meeting, St. Petersburg, Florida.

Mlawer, EJ, et al. 2004. "Status of the broadband heating rate profile (BBHRP) VAP." Proceedings of the 14th ARM Science Team Meeting, Albuquerque, New Mexico.

Payton, AM, JA Ogren, EG Dutton, PK Quinn, and JM Harris. 2004. "Development of aerosol models for radiative flux calculations." Proceedings of the 14th ARM Science Team Meeting, Albuquerque, New Mexico.

Sheridan, PJ, DJ Delene, and JA Ogren. 2001. "Four years of continuous surface aerosol measurements from the Department of Energy's Atmospheric Radiation Measurement program Southern Great Plains Cloud and Radiation Testbed site." Journal of Geophysical Research 106: 20,735-20,747.

Turner, DD, RA Ferrare, and LA Brasseur. 2001. "Average aerosol extinction and water vapor profiles over the Southern Great Plains." Geophysical Research Letters 28: 4441-4444.

Turner, DD, RA Ferrare, LA Heilman Brasseur, WF Feltz, and TP Tooman. 2002. "Automated retrievals of water vapor and aerosol profiles over Oklahoma from an operational Raman lidar." Journal of Atmospheric and Oceanic Technology 19: 37-50. 


\section{Appendix A}


Table 4. Input Platform and the associated fields.

\begin{tabular}{|c|c|}
\hline Input Datastreams & Key Input Fields \\
\hline nimfraod1mich, mfrsraod1mich & $\begin{array}{l}\text { aerosol_optical_depth_filter1 } \\
\text { qc_aerosol_optical_depth_filter1 } \\
\text { aerosol_optical_depth_filter2 } \\
\text { qc_aerosol_optical_depth_filter2 } \\
\text { aerosol_optical_depth_filter3 } \\
\text { qc_aerosol_optical_depth_filter3 } \\
\text { aerosol_optical_depth_filter4 } \\
\text { qc_aerosol_optical_depth_filter4 } \\
\text { aerosol_optical_depth_filter5 } \\
\text { qc_aerosol_optical_depth_filter5 } \\
\text { angstrom_exponent } \\
\text { qc_angstrom_exponent }\end{array}$ \\
\hline aip1ogren & $\begin{array}{l}\text { Bs_angstrom_exponent_BR_Dry_1um } \\
\text { Bs_G_Dry_1um_Neph3W_1 } \\
\text { Bbs_G_Dry_1um_Neph3W_1 } \\
\text { Bs_B_Dry_1um_Neph3W_1 } \\
\text { Bbs_B_Dry_1um_Neph3W_1 } \\
\text { Bs_R_Dry_1um_Neph3W_1 } \\
\text { Bbs_R_Dry_1um_Neph3W_1 } \\
\text { Ba_G_Dry_1um_PSAP1W_1 } \\
\text { Ba_G_Dry_1um_PSAP3W_1 } \\
\text { Ba_R_Dry_1um_PSAP3W_1 } \\
\text { Ba_B_Dry_1um_PSAP3W_1 } \\
\text { bsf_R_Dry_1um } \\
\text { bsf_G_Dry_1um } \\
\text { bsf_B_Dry_1um } \\
\text { RH_NephVol_Dry }\end{array}$ \\
\hline Aipfitrh1ogren & $\begin{array}{l}\text { fRH_Bs_G_1um_2p } \\
\text { fRH_Bs_B_1um_2p } \\
\text { fRH_Bs_R_1um_2p } \\
\text { fRH_Bbs_G_1um_2p } \\
\text { fRH_Bbs_B_1um_2p } \\
\text { fRH_Bbs_R_1um_2p } \\
\text { H_NephVol_Wet_max } \\
\text { RH_NephVol_Wet_min }\end{array}$ \\
\hline mergesonde1mace & $\begin{array}{l}\text { rh_scaled } \\
\text { height }\end{array}$ \\
\hline met(or smos) & Rh_mean \\
\hline
\end{tabular}




\section{Appendix B}


Table 5. Output variables for the monthly files.

\begin{tabular}{|c|c|c|}
\hline Output Fields & Long Name & Units \\
\hline be_aod_500 & best estimate aerosol optical depth at $500 \mathrm{~nm}$ & unitless \\
\hline be_aod_355 & best estimate aerosol optical depth at $355 \mathrm{~nm}$ & unitless \\
\hline be_angst_exp & best estimate Angström exponent & unitless \\
\hline height & height above ground level & $\mathrm{km}$ \\
\hline extinction_profile & aerosol extinction profile at $500 \mathrm{~nm}$ & $1 / \mathrm{km}$ \\
\hline single_scattering_albedo_red & $\begin{array}{l}\text { aerosol single scattering albedo profile at } 700 \\
\mathrm{~nm}\end{array}$ & unitless \\
\hline $\begin{array}{l}\text { single_scattering_albedo_gree } \\
\mathrm{n}\end{array}$ & $\begin{array}{l}\text { aerosol single scattering albedo profile at } 500 \\
\mathrm{~nm}\end{array}$ & unitless \\
\hline single_scattering_albedo_blue & $\begin{array}{l}\text { aerosol single scattering albedo profile at } 450 \\
\mathrm{~nm}\end{array}$ & unitless \\
\hline asymmetry_parameter_red & $\begin{array}{l}\text { aerosol asymmetry parameter profile at } 700 \\
\mathrm{~nm}\end{array}$ & unitless \\
\hline asymmetry_parameter_green & $\begin{array}{l}\text { aerosol asymmetry parameter profile at } 550 \\
\mathrm{~nm}\end{array}$ & unitless \\
\hline asymmetry_parameter_blue & $\begin{array}{l}\text { aerosol asymmetry parameter profile at } 450 \\
\mathrm{~nm}\end{array}$ & unitless \\
\hline scat_coeff_red & $\begin{array}{l}\text { aerosol total scatter coefficient at } 700 \mathrm{~nm} \text { for } \\
1 \mu \mathrm{m} \text { size cut }\end{array}$ & $1 / \mathrm{km}$ \\
\hline scat_coeff_green & $\begin{array}{l}\text { aerosol total scatter coefficient at } 550 \mathrm{~nm} \text { for } \\
1 \mu \mathrm{m} \text { size cut }\end{array}$ & $1 / \mathrm{km}$ \\
\hline scat_coeff_blue & $\begin{array}{l}\text { aerosol total scatter coefficient at } 450 \mathrm{~nm} \text { for } \\
1 \mu \mathrm{m} \text { size cut }\end{array}$ & $1 / \mathrm{km}$ \\
\hline backscatter_red & $\begin{array}{l}\text { aerosol back scatter coefficient at } 700 \mathrm{~nm} \text { for } \\
1 \mu \mathrm{m} \text { size cut }\end{array}$ & $1 / \mathrm{km}$ \\
\hline backscatter_green & $\begin{array}{l}\text { aerosol back scatter coefficient at } 550 \mathrm{~nm} \text { for } \\
1 \mu \mathrm{m} \text { size cut }\end{array}$ & $1 / \mathrm{km}$ \\
\hline backscatter_blue & $\begin{array}{l}\text { aerosol back scatter coefficient at } 450 \mathrm{~nm} \text { for } \\
1 \mu \mathrm{m} \text { size cut }\end{array}$ & $1 / \mathrm{km}$ \\
\hline absorp_coef_mean_red & $\begin{array}{l}\text { aerosol absorption coefficient at } 700 \mathrm{~nm} \text { for } 1 \\
\mu \mathrm{m} \text { size cut }\end{array}$ & $1 / \mathrm{km}$ \\
\hline absorp_coef_mean_green & $\begin{array}{l}\text { aerosol absorption coefficient at } 550 \mathrm{~nm} \text { for } 1 \\
\mu \mathrm{m} \text { size cut }\end{array}$ & $1 / \mathrm{km}$ \\
\hline absorp_coef_mean_blue & $\begin{array}{l}\text { aerosol absorption coefficient at } 450 \mathrm{~nm} \text { for } 1 \\
\mu \mathrm{m} \text { size cut }\end{array}$ & $1 / \mathrm{km}$ \\
\hline
\end{tabular}




\begin{tabular}{|c|c|c|}
\hline \multicolumn{3}{|c|}{ Table 5 (contd.) } \\
\hline Output Fields & Long Name & Units \\
\hline rh & relative humidity profile & $\%$ \\
\hline mean_aod_nimfr_filter1 & mean aerosol optical depth at $415 \mathrm{~nm}$ & unitless \\
\hline sdev_aod_nimfr_filter1 & $\begin{array}{l}\text { standard deviation of aerosol optical depth at } \\
415 \mathrm{~nm}\end{array}$ & unitless \\
\hline mean_aod_nimfr_filter2 & mean aerosol optical depth at $500 \mathrm{~nm}$ & unitless \\
\hline sdev_aod_nimfr_filter2 & $\begin{array}{l}\text { standard deviation of aerosol optical depth at } \\
500 \mathrm{~nm}\end{array}$ & unitless \\
\hline mean_aod_nimfr_filter3 & mean aerosol optical depth at $615 \mathrm{~nm}$ & unitless \\
\hline sdev_aod_nimfr_filter3 & $\begin{array}{l}\text { standard deviation of aerosol optical depth at } \\
615 \mathrm{~nm}\end{array}$ & unitless \\
\hline mean_aod_nimfr_filter4 & mean aerosol optical depth at $673 \mathrm{~nm}$ & unitless \\
\hline sdev_aod_nimfr_filter4 & $\begin{array}{l}\text { standard deviation of aerosol optical depth at } \\
673 \mathrm{~nm}\end{array}$ & unitless \\
\hline mean_aod_nimfr_filter5 & mean aerosol optical depth at $870 \mathrm{~nm}$ & unitless \\
\hline sdev_aod_nimfr_filter5 & $\begin{array}{l}\text { standard deviation of aerosol optical depth at } \\
870 \mathrm{~nm}\end{array}$ & unitless \\
\hline mean_angst_exponent_nimfr & $\begin{array}{l}\text { mean Angström exponent from NIMFR } \\
\text { observations }\end{array}$ & unitless \\
\hline $\begin{array}{l}\text { interpolated_angst_exponent_n } \\
\text { imfr }\end{array}$ & $\begin{array}{l}\text { Interpolated Angström exponent from NIMFR } \\
\text { observations }\end{array}$ & unitless \\
\hline mean_aod_mfrsr_filter1 & mean aerosol optical depth at $415 \mathrm{~nm}$ & unitless \\
\hline sdev_aod_mfrsr_filter1 & $\begin{array}{l}\text { standard deviation of aerosol optical depth at } \\
415 \mathrm{~nm}\end{array}$ & unitless \\
\hline mean_aod_mfrsr_filter2 & mean aerosol optical depth at $500 \mathrm{~nm}$ & unitless \\
\hline sdev_aod_mfrsr_filter2 & $\begin{array}{l}\text { standard deviation of aerosol optical depth at } \\
500 \mathrm{~nm}\end{array}$ & unitless \\
\hline mean_aod_mfrsr_filter3 & mean aerosol optical depth at $615 \mathrm{~nm}$ & unitless \\
\hline sdev_aod_mfrsr_filter3 & $\begin{array}{l}\text { standard deviation of aerosol optical depth at } \\
615 \mathrm{~nm}\end{array}$ & unitless \\
\hline mean_aod_mfrsr_filter4 & mean aerosol optical depth at $673 \mathrm{~nm}$ & unitless \\
\hline
\end{tabular}




\begin{tabular}{|c|c|c|}
\hline \multicolumn{3}{|c|}{ Table 5 (contd.) } \\
\hline Output Fields & Long Name & Units \\
\hline sdev_aod_mfrsr_filter4 & $\begin{array}{l}\text { standard deviation of aerosol optical depth at } \\
673 \mathrm{~nm}\end{array}$ & unitless \\
\hline mean_aod_mfrsr_filter5 & mean aerosol optical depth at $870 \mathrm{~nm}$ & unitless \\
\hline sdev_aod_mfrsr_filter5 & $\begin{array}{l}\text { standard deviation of aerosol optical depth at } \\
870 \mathrm{~nm}\end{array}$ & unitless \\
\hline mean_angst_exponent_mfrsr & $\begin{array}{l}\text { mean Angström exponent from MFRSR } \\
\text { observations }\end{array}$ & unitless \\
\hline $\begin{array}{l}\text { interpolated_angst_exponent_ } \\
\text { mfrsr }\end{array}$ & $\begin{array}{l}\text { interpolated Angström exponent from } \\
\text { MFRSR observations }\end{array}$ & unitless \\
\hline mean_aod_rl & $\begin{array}{l}\text { mean aerosol optical depth from Raman lidar } \\
\text { at } 355 \mathrm{~nm}\end{array}$ & unitless \\
\hline height_rl & height above ground level from Raman Lidar & $\mathrm{km}$ \\
\hline rh_rl & Relative humidity profile from Raman Lidar & $\%$ \\
\hline angst_exponent_rl & $\begin{array}{l}\text { Angström exponent derived from Raman lidar } \\
\text { and MFRSR at } 870 \mathrm{~nm} \text { observations }\end{array}$ & unitless \\
\hline angst_exponent_mfrsr_filter2 & $\begin{array}{l}\text { Angström exponent derived from MFRSR at } \\
450 \mathrm{~nm} \text { observations }\end{array}$ & unitless \\
\hline angst_exponent_mfrsr_filter2 & $\begin{array}{l}\text { Angström exponent derived from MFRSR at } \\
450 \mathrm{~nm} \text { observations }\end{array}$ & unitless \\
\hline angst_exponent_rl_filled & $\begin{array}{l}\text { filled Angström exponent derived from } \\
\text { Raman lidar and MFRSR at } 870 \mathrm{~nm} \\
\text { observations }\end{array}$ & unitless \\
\hline angstrom_exponent_AOS & $\begin{array}{l}\text { Angström exponent computed from } \\
\text { humidified submicron total scattering } \\
\text { coefficients at } 450 \mathrm{~nm} \text { and } 700 \mathrm{~nm} \text { for } 1 \mu \mathrm{m} \\
\text { size cut }\end{array}$ & unitless \\
\hline GrnTscat_humidified & $\begin{array}{l}\text { humidified total scatter coefficient at } 500 \mathrm{~nm} \\
\text { for } 1 \mu \mathrm{m} \text { size cut }\end{array}$ & $1 / \mathrm{km}$ \\
\hline GrnBscat_humidified & $\begin{array}{l}\text { humidified backscatter coefficient at } 500 \mathrm{~nm} \\
\text { for } 1 \mu \mathrm{m} \text { size cut }\end{array}$ & $1 / \mathrm{km}$ \\
\hline BluTscat_humidified & $\begin{array}{l}\text { humidified total scatter coefficient at } 450 \mathrm{~nm} \\
\text { for } 1 \mu \mathrm{m} \text { size cut }\end{array}$ & $1 / \mathrm{km}$ \\
\hline BluBscat_humidified & $\begin{array}{l}\text { humidified backscatter coefficient at } 450 \mathrm{~nm} \\
\text { for } 1 \mu \mathrm{m} \text { size cut }\end{array}$ & $1 / \mathrm{km}$ \\
\hline RedTscat_humidified & $\begin{array}{l}\text { humidified total scatter coefficient at } 700 \mathrm{~nm} \\
\text { for } 1 \mu \mathrm{m} \text { size cut }\end{array}$ & $1 / \mathrm{km}$ \\
\hline
\end{tabular}


Table 5 (contd.)

\begin{tabular}{|c|c|c|}
\hline Output Fields & Long Name & Units \\
\hline RedBscat_humidified & $\begin{array}{l}\text { humidified backscatter coefficient at } 700 \mathrm{~nm} \\
\text { for } 1 \mu \mathrm{m} \text { size cut }\end{array}$ & $1 / \mathrm{km}$ \\
\hline rh_mean_surf_boundary & $\begin{array}{l}\text { Mean of relative humidity from sonde from } \\
\text { surface to boundary level }\end{array}$ & unitless \\
\hline predicted_aod & $\begin{array}{l}\text { Predicted Aerosol Optical Depth using linear } \\
\text { regression }\end{array}$ & unitless \\
\hline boundary_layer & boundary layer mixing height & $\mathrm{km}$ \\
\hline rh_mwrp & $\begin{array}{l}\text { Relative humidity profile from microwave } \\
\text { radiometer profiler }\end{array}$ & $\%$ \\
\hline mean_aod_aos & $\begin{array}{l}\text { Mean aerosol optical depth derived from } \\
\text { extinction profile at NSA }\end{array}$ & unitless \\
\hline extinction_profile_scaled & Scaled Aerosol extinction profile at $500 \mathrm{~nm}$ & $1 / \mathrm{km}$ \\
\hline extinction_profile_aos & Aerosol extinction profile at $500 \mathrm{~nm}$ & $1 / \mathrm{km}$ \\
\hline extinction_profile_clim & $\begin{array}{l}\text { Aerosol extinction profile at } 500 \mathrm{~nm} \text { or } \\
\text { Climatological Aerosol extinction profile at } \\
500 \mathrm{~nm}\end{array}$ & $1 / \mathrm{km}$ \\
\hline rh_sonde & Relative humidity profile from sonde & $\%$ \\
\hline solar_zenith_angle & Solar zenith angle & degree \\
\hline fRH_Bs_R_1um_2p & $\begin{array}{l}\text { Coefficients for } 2 \text { parameter fit of } \mathrm{Bs} \text {. R_lum } \\
\text { hygroscopic growth as a function of } \mathrm{RH}\end{array}$ & unitless \\
\hline fRH_Bs_G_1um_2p & $\begin{array}{l}\text { Coefficients for } 2 \text { parameter fit of Bs_G_1um } \\
\text { hygroscopic growth as a function of } \mathrm{RH}\end{array}$ & unitless \\
\hline fRH_Bs_B_1um_2p & $\begin{array}{l}\text { Coefficients for } 2 \text { parameter fit of Bs_B_1um } \\
\text { hygroscopic growth as a function of } \mathrm{RH}\end{array}$ & unitless \\
\hline fRH_Bbs_R_1um_2p & $\begin{array}{l}\text { Coefficients for } 2 \text { parameter fit of } \\
\text { Bbs_R_1um hygroscopic growth as a function } \\
\text { of } \mathrm{RH}\end{array}$ & unitless \\
\hline $\mathrm{fRH}$ _Bbs_G_1um_2p & $\begin{array}{l}\text { Coefficients for } 2 \text { parameter fit of } \\
\text { Bbs_G_1um hygroscopic growth as a function } \\
\text { of } \mathrm{RH}\end{array}$ & unitless \\
\hline fRH_Bbs_B_1um_2p & $\begin{array}{l}\text { Coefficients for } 2 \text { parameter fit of } \\
\text { Bbs_B_1um hygroscopic growth as a function } \\
\text { of } \mathrm{RH}\end{array}$ & unitless \\
\hline RH_NephVol_Dry & Relative humidity inside dry nephelometer & $\%$ \\
\hline
\end{tabular}




\begin{tabular}{|l|l|l|}
\hline \multicolumn{2}{|c|}{ Table 5 (contd.) } & Units \\
\hline Output Fields & Long Name & unitless \\
\hline ratio_Bs_R_1um & $\begin{array}{l}\text { Computed ratio of Bs_R_1um at rh\% and } \\
\text { RH_NephVol_Dry }\end{array}$ & unitless \\
\hline ratio_Bs_G_1um & $\begin{array}{l}\text { Computed ratio of Bs_G_1um at rh\% and } \\
\text { RH_NephVol_Dry }\end{array}$ & unitless \\
\hline ratio_Bs_B_1um & $\begin{array}{l}\text { Computed ratio of Bs_B_1um at rh\% and } \\
\text { RH_NephVol_Dry }\end{array}$ & unitless \\
\hline ratio_Bbs_R_1um & $\begin{array}{l}\text { Computed ratio of Bbs_R_1um at rh\% and } \\
\text { RH_NephVol_Dry }\end{array}$ & unitless \\
\hline ratio_Bbs_G_1um & $\begin{array}{l}\text { Computed ratio of Bbs_G_1um at rh\% and } \\
\text { RH_NephVol_Dry }\end{array}$ & unitless \\
\hline ratio_Bbs_B_1um & $\begin{array}{l}\text { Computed ratio of Bbs_B_1um at rh\% and } \\
\text { RH_NephVol_Dry }\end{array}$ & unitless \\
\hline aod_source_flag & $\begin{array}{l}\text { flag indicating source of best-estimate AOD } \\
\text { at 500 nm }\end{array}$ & unitless \\
\hline rh_source & flags describing source of RH & \\
\hline
\end{tabular}




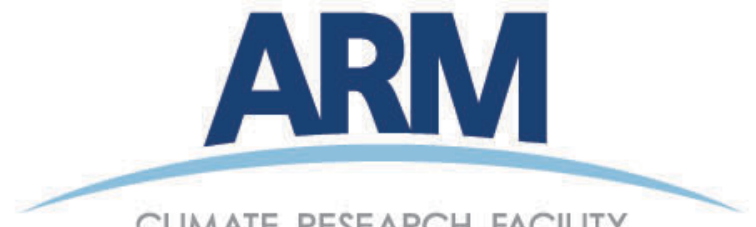

CLIMATE RESEARCH FACILITY

www.arm.gov

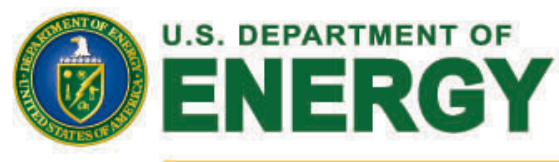

Office of Science 